\title{
Inhibition of Interleukin-1-Induced Effects in Synoviocytes Transduced with the Human IL-1 Receptor Antagonist cDNA Using an Adenoviral Vector
}

\author{
BLAKE J. ROESSLER, JOHN W. HARTMAN, DAVID K. VALLANCE, JILL M. LATTA, \\ SONIA L. JANICH, and BEVERLY L. DAVIDSON
}

\begin{abstract}
In this report, we present data showing that a recombinant adenoviral vector (Ad.RSVIL-1ra) containing the cDNA for human interleukin-1 receptor antagonist protein (IL-1ra) can genetically modify synoviocytes both in vitro and in vivo. Human synoviocytes infected with Ad.RSVIL-1 ra in vitro expressed and secreted high levels of human IL-1ra that were detected by ELISA of tissue culture supernatants. New Zealand White rabbits that received intra-articular injections of Ad.RSVIL-1ra expressed transgenic IL-1ra in synoviocytes, and secretion was detected for at least 4 weeks post-infection. Further, biological activity of the transgenic IL-1ra was demonstrated by its ability to inhibit IL-1-induced prostaglandin $\mathrm{E}_{2}\left(\mathrm{PGE}_{2}\right)$ synthesis in vitro and IL-I-induced glycosaminoglycan (GAG) degradation in vivo. These data demonstrate that recombinant adenoviral vectors can inediate the intra-articular expression of anti-inflammatory proteins and may be a reasonable method to deliver therapeutically relevant proteins for the regional treatinent of synovial inflammation.
\end{abstract}

\section{OVERVIEW SUMMARY}

Adenovirus-mediated gene transfer into the cells of the synovial membrane may provide a means to deliver therapeutically active proteins for the local modification of the immune response in inflammatory arthropathies. In this study, we infected type $B$ human synoviocytes in vitro and rabbit synovial lining membrane in vivo with a recombinant human adenovirus containing the $\mathrm{CDNA}$ for the human interleukin-1 receptor antagonist protein (IL-1ra). Expression of human IL-1ra was observed both in the transduced synoviocytes in vitro and in the microenvironment of the transduced rabbit synovial membrane in vivo, and the functional activity of the transgenic IL-1ra was suggested by in vitro inhibition of interleukin-1 (IL-1)-induced prostaglandin $\mathrm{E}_{2}\left(\mathrm{PGE}_{2}\right)$ production and by in vivo inhibition of IL-1induced glycosaminoglycan (GAG) degradation.

\section{INTRODUCTION}

D IARTHRODIAL JOINTS ARE LINED BY SYNOVIAL MEMBRANE, a complex multifunctional mesothelial layer of one to four cells supported by loose vascular connective tissue. Ultrastructural studies of the synovial membrane have indicated that at least two major types of cells are present within the synovial membrane (Barland et al., 1962). Type A cells have phagocytic capability and endocytic vacuoles, and are thought to be derived from the monocyte lineage. Type B cells, in contrast, have secretory features such as an active Golgi, abundant endoplasmic reticulum, and intracytoplasmic granules. These cells are believed to be specialized mesenchymal cells of fibroblast origin. In addition, cells with an intermediate ultrastructural appearance and morphology may exist within adult synovium (Roy et al., 1966).

In inflamed joints, the synovial lining increases to five to ten 
cell layers, primarily by the accumulation of type A synoviocytes (Broker et al., 1990). At the same time, the formerly quiescent type B cells change into aggressive, proliferating, invasive cells that display many features of a "transformed" phenotype, such as oncogene expression and metalloprotease excretion (Lafyatis et al., 1989; Gay et al., 1993). Previous work has shown that these changes in the synovial membrane are mediated by a variety of effector molecules associated with rheumatoid arthritis, and synoviocytes themselves have been shown to secrete several of these cytokines (Harris, 1990).

One of these cytokines, interleukin-1 (IL-1), functions as a central mediator of inflammation. Multiple studies have elucidated the importance of regional IL-1 production in the generation and maintenance of synovial inflammation (Wood et al., 1985; Miossec et al., 1986; Mochan et al., 1986; Kumkumian et al., 1989). IL-1 stimulates IL-2 production and induces the expression of IL-2 receptors on T cells (Smith et al., 1980). These effects permit antigen-stimulated $T$ cells to expand in number. 1L-1 is also critical for B-cell proliferation and immunoglobulin production (Falkoff et al., 1984). In addition, IL-1 stimulates type B synoviocytes to secrete metalloproteases, such as stromelysin (Mizel et al., 1981; Dayer et al., 1984; 1986; McCroskery et al., 1985; Stashenko et al., 1987; Case et al., 1989). IL-1 also induces prostaglandin $\mathrm{E}_{2}\left(\mathrm{PGE}_{2}\right)$ production (Mizel et al., 1981; Dayer et al., 1986) and glycosaminoglycan (GAG) degradation (Yaron et al, , 1987).

An endogenous interleukin-1 receptor antagonist protein (IL1ra) has previously been isolated and cloned. This natural antagonist protein is structurally related to IL- $1 \alpha$ and IL- $1 \beta$ and competes with these cytokines for occupancy of IL-1 cell-surface receptors. Since 1L-1ra does not trigger signal transduction, it functions as a competitive inhibitor. Previous studies have demonstrated that many IL- 1 effects can be blocked by native IL-1 $\mathrm{ra}$, such as the induction of $\mathrm{PGE}_{2}$ synthesis by synovial cells and fibroblasts (Seckinger et al., 1987; Arend et al., 1989), the inhibition of GAG production in human articular cartilage cultures (Seckinger et al., 1990), the stimulation of hyaluronic acid production by human synoviocytes (Seckinger et al., 1990), and the production of collagenase by rabbit articular chondrocytes (Arend et al., 1989).

The recent characterization of IL-1 ra suggests that this protein plays a crucial role in regulating IL-1 activity, and has raised the possibility of using this molecule as a therapeutic agent. Regional overexpression of this molecule would be expected to reduce tissue inflammation by inhibiting IL-1 activity (Stashenko et al., 1987; Arend et al., 1990; Carter et al., 1990; Eisenberg et al., 1990; Dinarello, 1992). Gene therapy provides a testable method for augmenting the local production of IL-1ra. Previous studies have shown the feasibility of this approach by demonstrating that synovial tissues can be modified to secrete IL-1 a following ex vivo retroviral transduction (Bandara et al., 1993). Further, the ultrastructural organization of the synovial membrane suggests that synovitis may be especially suited to gene therapy. The synovial lining cells lack a clearly defined basement membrane, and endothelial cells (up to $10 \%$ of the total cell population) are directly subjacent to this membrane. The lack of any anatomic barrier between the lining cells and the endothelium suggests that overexpression of soluble cytokine inhibitors by synovial cells may cause clinically relevant effects within the local microenvironment with regard to inflammatory cell recruitment, retention, and activation. If sufficient levels of cytokine inhibitor expression were present, an anti-inflammatory effect might be observed within the intraarticular space of a specific joint.

In the current report, we describe the construction of an adenoviral vector containing the cDNA for human IL-1ra (Ad.RSVIL-1ra) and provide data showing that both human synovium transduced by Ad. RSVIL-Ira in vitro and rabbit synovial tissue transduced by Ad.RSVIL-Ira in vivo secrete biologically active IL-1 ra.

\section{MATERIALS AND METHODS}

\section{Generation of Ad.RSVIL-1 ra}

Ad.RSVIL-1ra is a replication-defective adenoviral vector based on an Ad5 serotype viral genomic backbone. This virus is deleted of sequences spanning E1A and E1B (1-9 map units), resulting in an impaired ability to replicate or to transform nonpermissive cells (Logan et al., 1984; Davidson et al., 1993). The E1B deletion interrupts the E1B-19K coding region. In addition, the recombinants are deleted in the $E 3$ region (83-85 map units). This deletion interrupts the open reading frames (ORFs) for the E3 region immunomodulatory genes gp19K, 14.7K, and 10.4/14.5K. The Rous sarcoma virus (RSV) LTR drives the transgene transcription in this recombinant vector. To construct this vector, the RSV promoter and the cDNA for human IL-1ra (a gift from Immunex, Seattle, WA) were cloned into the parent plasmid pAd.BglII to generate the plasmid pAd.RSVIL-Ira. [This proviral plasmid provides the 5 ' inverted terminal repeat (ITR) sequence necessary for viral replication and encapsidation.] pAd.RSVIL-I $r a$ was linearized by Nhe I digestion and cotransfected into permissive 293 cells with viral genomic DNA (Ad5 derivative sub360), which had been previously digested with $\mathrm{Xba}$ I and $\mathrm{Cla}$ I to achieve the E1-region deletion (Graham and Van Der Eb, 1973). As a result of homologous recombination (within 9.2-16.1 map units), an ElA/E1B-deleted recombinant adenovirus (Ad.RSVIL-lra) containing the human IL-1 ra CDNA was produced.

Candidate plaques were expanded and the identity of recombinant clones was verified by restriction analysis of viral DNA minipreps. High-titer viral suspensions for in vitro and in vivo studies were produced by amplification of triple plaque-purified stocks in 293 cells using a modification of established methods (Graham and Van Der Eb, 1973). Control viruses for in vitro and in vivo experiments were Ad.BglII (an identical Ad5-derived adenoviral vector that does not contain a functional transgene) and Ad.RSVlacZ (an Ad5 vector containing the gene for $E$. coli $\beta$-galactosidase). (Analyses of viral stocks for human IL-1ra were below the detection limits of the commercial ELISA [ $<46 \mathrm{pg} / \mathrm{ml}]$.)

\section{In vitro infection of human synoviocytes}

Human type-B synoviocytes obtained from surgical specimens at the time of elective prosthetic joint replacement were kindly provided by Dr. C.W. Castor. Explanted synoviocytes were characterized phenotypically by the use of a $\left[{ }^{14} \mathrm{C}\right] \mathrm{glu}$ cosamine to $\left[{ }^{14} \mathrm{C}\right]$ hyaluronic acid incorporation assay (Castor, 
1971). Synoviocytes were maintained in subconfluent monolayer cultures in air in T-75 flasks in CMRL 1066 medium (GIBCO BRL, Grand Island, NY) supplemerted with 5\% human serum, $5 \%$ fetal calf serum (FCS), $10 \%$ neonatal calf serum, $0.025 \%$ sodium bicarbonate, $2 \mathrm{mM}$ L-glutamine, 0.02 $M$ HEPES buffer, penicillin $(100 \mathrm{U} / \mathrm{ml})$, streptomycin $(100$ $\mu \mathrm{g} / \mathrm{ml})$, and gentamicin $(5 \mu \mathrm{g} / \mathrm{ml})$. Synoviocytes were infected with purified suspensions of Ad.RSVIL-I ra at multiplicities of infection (moi) ranging from $10^{2}-10^{4}$ plaque forming units (pfu) per cell for a period of $4 \mathrm{hr}$, then grown out and maintained as confluent monolayer cultures for 7 days post-infection. At 1, 4, and 7 days post-infection, cells were washed twice in PBS and then covered with fresh, serum-free CMRL 1066 for $2 \mathrm{hr}$. Tissue culture supernatants were removed, centrifuged to remove cell debris, and frozen at $-70^{\circ} \mathrm{C}$. No significant cytopathic effect was observed in the infected cells, which continued to grow at rates comparable to uninfected controls and to exhibit contact inhibition at confluence. The amount of human IL-1ra present in the tissue culture supernatants was determined using an ELISA specific for human IL-1 ra (R \& D Systems, Minneapolis, MN) according to the manufacturer's instructions.

\section{$P G E_{2}$ assays}

Third-passage rheumatoid synoviocytes were exposed to Ad.RSVlacZ or Ad.RSVIL-1 ra, at a titer of $10^{4}$ plaque forming units per synoviocyte for a period of $2 \mathrm{hr}$ in CMRL 1066 supplemented with $2 \%$ FCS. The cells were then grown out in complete CMRL 1066 medium. Three days post-infection, multiple samples of synoviocytes $(n=10)$ were treated with medium supplemented with $1 \%$ BSA and recombinant human IL-1 $\beta$ (rhIL-1 $\beta, 3 \mathrm{U} / \mathrm{ml}$; Genzyme, Cambridge, MA). After 12 $\mathrm{hr}$, the production of $\mathrm{PGE}_{2}$ by the synoviocytes in response to stimulation with rhIL-1 $\beta$ was determined by ELISA (PerSeptive Diagnostics, Cambridge MA) of tissue culture supernatants. Results were expressed as picograms of $\mathrm{PGE}_{2}$ per milliliter of supernatant.

\section{In vivo studies}

Animal experiments were performed in accordance with institutional guidelines and approved by the University Committee on Use and Care of Animals. New Zealand White (NZW) rabbits $2 \mathrm{~kg}$ in weight were used for these experiments, and freshly prepared suspensions of Ad.RSVIL-Ira were used for intra-articular injections. Prior to the procedure, rabbits were anesthetized with a single intramuscular dose of ketamine/ xylazine. The area surrounding both hind knees was shaved and coated with providone/iodine. Using sterile technique and a medial approach, $1 \mathrm{ml}$ of Ad.RSVIL-1 ra suspension in phosphate-buffered saline (PBS) was injected into the intra-articular space of the right knee over a period of $30 \mathrm{sec}$. The left knee was prepared in an identical manner and injected with $1 \mathrm{ml}$ of PBS or $1 \mathrm{ml}$ of a control virus (Ad.BgIII or Ad.RSVlacZ). At time points from 4 days to 4 weeks post-infection, animals were euthanized with an intravenous overdose of pentobarbital. Skin and fascia were dissected away from the region of the knee and the joint space was exposed through an incision made along the medial border of the patellofemoral ligament. The joint space was lavaged with $2 \mathrm{ml}$ of PBS over a period of approximately 2 $\mathrm{min}$, and the lavage fluid was recovered by aspiration. The fluid was centrifuged for $5 \mathrm{~min}$ at $10,000 \times g$ to remove cellular debris and aliquots were frozen at $-70^{\circ} \mathrm{C}$ until use. Representative samples of synovial tissue were dissected away from surrounding structures and were frozen in OCT.

\section{RESULTS}

The ability of the virus Ad.RSVIL-Ira to transduce human synoviocytes and to mediate the expression of human 1L-1 ra was determined using human synoviocytes in vitro. Human type B synoviocytes were infected with purified suspensions of Ad.RSVIL-1 ra at various moi from $10^{2}-10^{4} \mathrm{pfu} / \mathrm{cell}$ for a period of $4 \mathrm{hr}$, rinsed, and then maintained as confluent monolayer cultures for 7 days post-infection. The rate of transgenic IL-1ra production by the infected synoviocytes in vitro was determined at 1, 4, and 7 days post infection using an ELISA specific for human IL-1 ra (R\&D Systems). Ad.RSVIL-Ira was able to mediate expression and secretion of human IL-1ra by infected synoviocytes, with the concentration of $1 \mathrm{~L}-1$ ra ranging from 10 to $100 \mu \mathrm{g} / \mathrm{hr} \cdot \mathrm{mg}$ of total protein in supernatants (Table 1).

Southern analysis was used to determine the transgenic ILIra copy number using total cellular DNA obtained from dupli-

TABLE 1. In Vitro EXPRESSION AND SECRETION OF HUMAN IL-lRA PROTEIN BY HUMAN SYNOVIOCYTES INFECTED WITH AD.RSVIL-Ira

\begin{tabular}{lcr}
\hline Virus: moi (pfu/cell) & Days post-infection & $I L-I r a^{a}$ \\
\hline Ad.RSVIL-Ira: & 1 & \\
$10^{2}$ & 4 & 0.02 \\
$10^{2}$ & 7 & 11.80 \\
$10^{2}$ & 1 & 10.60 \\
$10^{3}$ & 4 & 0.70 \\
$10^{3}$ & 7 & 35.80 \\
$10^{3}$ & 1 & 28.00 \\
$10^{4}$ & 4 & 1.68 \\
$10^{4}$ & & 115.60 \\
Ad.RSVlacZ: & 1 & \\
$10^{4}$ & 7 & $<0.01$ \\
$10^{4}$ & 7 & $<0.01$ \\
\hline
\end{tabular}

Human synoviocytes were maintained in monolayer cultures in air in T-75 flasks in CMRL 1066 medium (GIBCO) supplemented with 5\% human serum, $5 \%$ FCS, $10 \%$ neonatal calf serum, $0.025 \%$ sodium bicarbonate, $2 \mathrm{~m} M$ L-glutamine, $0.02 M$ HEPES, penicillin $(100 \mathrm{U} / \mathrm{ml})$, streptomycin $(100 \mu \mathrm{g} / \mathrm{ml})$, and gentamicin $(5 \mu \mathrm{g} / \mathrm{ml})$. Synoviocytes were then infected in serum free medium at moi from $10^{2}$ to $10^{4}$ viral particles per target cell with Ad.RSVIL-1 $\mathrm{ra}$, and $10^{4}$ viral particles per cell for Ad.RSVlacZ (control) for $4 \mathrm{hr}$, washed extensively, and maintained as confluent cultures for 7 days. At 1, 4, and 7 days postinfection, the synoviocytes were washed twice in PBS and then exposed to serum-free tissue culture medium for a period of $2 \mathrm{hr}$. Tissue culture supernatants were collected and frozen at $-70^{\circ} \mathrm{C}$ until use. Supernatants were then analyzed using an ELISA specific for human IL-lra (R\&D Systems). Total protein concentration in the supernatants was determined using the method of Lowry.

"lL-l ra production is expressed as $\mu \mathrm{g} / \mathrm{hr} \cdot \mathrm{mg}$ of total protein present in $10 \mathrm{ml}$ of serum-free tissue culture supernatant collected over a period of $2 \mathrm{hr}$. 
cate aliquots of the infected cells harvested $48 \mathrm{hr}$ post-infection. IL-1ra-specific sequences were detected as DNA fragments consistent with the known size of the parent adenoviral genome, the endogenous IL-1 ra gene, and the transgenic human IL-1ra cDNA (Fig. 1, arrows). Although the occurrence of rare integrative events could not be excluded, no additional bands were observed when blots were overexposed (data not shown). Analysis of the blots using a phosphoimager (Molecular Dynamics, Sunnyvale, CA) indicated that the number of viral genomes per target cell correlated with increasing doses of virus up to a moi of $10^{4} \mathrm{pfu} / \mathrm{cell}$, the highest dose tested.

An in vitro assay using Ad.RSVIL-l ra transduced synoviocytes was done to determine if the transgenic IL-1ra produced was biologically active. This assay was designed to test the ability of IL-1 ra to inhibit the production of $\mathrm{PGE}_{2}$ in response to stimulation with exogenous recombinant human IL-1 $\beta$ (Fig. 2). Synoviocytes infected with Ad.RSVIL-Ira produced significantly less $\mathrm{PGE}_{2}$ over $12 \mathrm{hr}$ of incubation with rhIL-1 $\beta$ than cells infected with Ad.RSVlacZ $(p<0.001)$ or uninfected controls $(p<0.001)$. No significant difference was observed in $\mathrm{PGE}_{2}$ production between mock-infected synoviocytes and synoviocytes infected with Ad.RSVlacZ ( $p=0.067$ ).

Normal rabbit synovium was used as a target tissue to test the ability of Ad.RSVIL-1 ra to mediate transgenic expression of biologically active IL-1 ra in vivo. Rabbits received intra-articular injections of purified Ad.RSVIL-Ira suspension $\left(2.0 \times 10^{10} \mathrm{pfu} / \mathrm{mL}\right)$ in PBS (total volume $\left.1 \mathrm{ml}\right)$ in the right knees. The left knee was prepared in an identical manner and injected with $1 \mathrm{ml}$ of PBS or $1 \mathrm{ml}$ of the control virus (Ad.BglII or Ad.RSVlacZ). None of the rabbits experienced evidence of clinically relevant arthritis as determined by their ability to ambulate in their cages, lack of change in serially measured articular circumference, and absence of erythema overlying the periarticular skin. At 1-4 weeks post-infection, animals were euthanized with an intravenous overdose of pentobarbital and the synovial tissue examined for the expression of transgenic human IL-1 ra using in situ RNA hybridization.

Sections of rabbit synovium transduced with Ad. RSVIL-1 ra 1 week previously hybridized strongly to probes antisense to human IL-1ra sequences (Fig. 3B). Importantly, samples of synovium infected with Ad.RSVlacZ (Fig. 3A) showed no increase over background levels of antisense or sense probe hybridization (Fig. 3C), indicating that the signal seen in B is due to transgenic IL-1 ra and not to up-regulated expression of endogenous rabbit IL-1ra. Similar negative results were seen when antisense probe was hybridized to sections of synovium from rabbit knees injected with PBS or Ad.BglII (data not shown). Although the signal at 1 week was uniformly strong, synovial tissue sections from animals sacrificed 2 and 4 weeks post-infection had only scattered positive synoviocytes (data not shown).

The ability of synovial cells to secrete IL-1ra in vivo was determined by ELISA of lavage fluid. The normal rabbit knee contains little joint fluid, and importantly the rabbits did not develop joint effusions as a result of the intra-articular infection procedure. Therefore, the amount of transgenic IL-1 ra present within the knee joint at the time of sacrifice was determined indirectly by performing a post-mortem medial arthrotomy followed by articular lavage with $2 \mathrm{ml}$ of PBS. Fluid was collected by aspiration of the joint space, cellular debris removed by

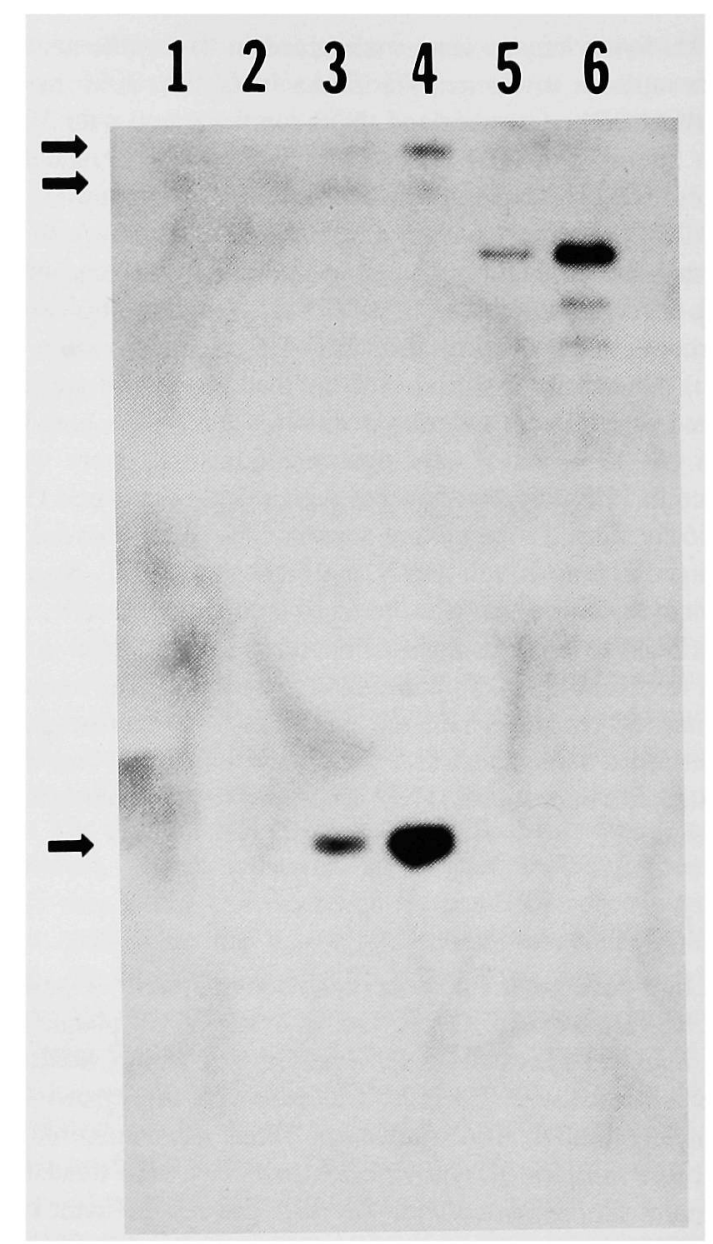

FIG. 1. Southern analysis of human synoviocytes infected in vitro with Ad.RSVIL-Ira. Human synoviocytes were maintained in monolayer cultures in air in T-75 flasks in CMRL 1066 medium (GIBCO) supplemented with 5\% human serum, $5 \%$ fetal bovine serum, $10 \%$ neonatal calf serum, $0.025 \%$ sodium bicarbonate, $2 \mathrm{~m} M$ L-glutamine, $0.02 M$ HEPES buffer, penicillin $(100 \mathrm{U} / \mathrm{ml})$, streptomycin $(100 \mu \mathrm{g} / \mathrm{ml})$, and gentami$\operatorname{cin}(5 \mu \mathrm{g} / \mathrm{ml})$. Synoviocytes were then infected in serum-free medium at moi from $10^{2}$ to $10^{4}$ viral particles per target cell with Ad.RSVIL-I ra, and $10^{4}$ viral particles per cell for Ad.RSVlacZ (control) for $4 \mathrm{hr}$, washed extensively, maintained in culture, and harvested 2 days post-infection. Total cellular DNA was isolated from the cells using standard methods. Ten micrograms of total cellular DNA and $1 \mathrm{pg}$ and $10 \mathrm{pg}$ of purified plasmid DNA from pAd.RSVIL-Ira were digested with $B a m$ HI (human IL-1 ra cDNA contains a single Bam $\mathrm{HI}$ site) and analyzed by Southern blot using ${ }^{32} \mathrm{P}$-labeled probes specific for human IL-1 ra cDNA. Note the dose-dependent increase in copy number observed in the infected synoviocytes with respect to both adenoviral genomic DNA (upper arrow) and human IL-1 ra cDNA (lower arrow). The middle arrow indicates the location of the human IL-1 ra gene $(11 \mathrm{~kb})$ and is consistent in intensity across all lanes. Quantitative analysis of the blots using a Molecular Dynamics phosphoimager was used to estimate the average number of adenoviral genomes/synoviocyte. Lane 1, Ad.RSVlacZ-infected cells $\left(\mathrm{moi}=10^{3}\right.$ ); lane 2, Ad.RSVILIra-infected cells ( $\mathrm{moi}=10^{2}, 0.5$ copies/cell); lane 3, Ad.RSVIL-Ira-infected cells (moi $=10^{3}, 1.0$ copies/cell); lane 4, Ad.RSVIL-1 $\mathrm{ra}$-infected cells $\left(\mathrm{moi}=10^{4}, 6.0\right.$ copies $/$ cell); lanes 5 and $6,1 \mathrm{pg}$ and $10 \mathrm{pg}$ of pAd.RSVIL-Ira. 


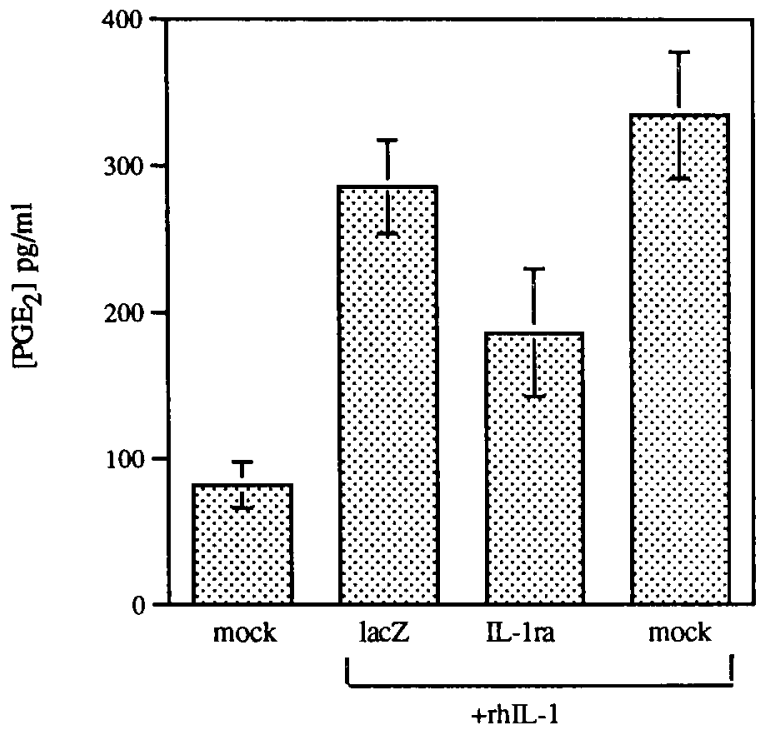

FIG. 2. $\mathrm{PGE}_{2}$ production by cultured human synoviocytes in vitro after IL-1 $\beta$ stimulation. Multiple cultures of human rheumatoid synoviocytes from the same subject $(n=10)$ were infected with recombinant adenovirus (Ad.RSVlacZ or Ad.RSVIL-Ira at a moi of $10^{4} \mathrm{pfu} / \mathrm{cell}$ ). Mock-infected cells were carried in parallel. Three days later, cells were stimulated with rhlL- $1 \beta(3 \mathrm{U} / \mathrm{ml})$ for a period of $12 \mathrm{hr}$ in serum-free media. The total production of soluble $\mathrm{PGE}_{2}$ by the experimental and control synoviocytes was determined by ELISA (PerSeptive Diagnostics) of tissue culture supernatants, and the data expressed as picograms $\mathrm{PGE}_{2}$ per milliliter. Uninfected cells produced significant amounts of soluble $\mathrm{PGE}_{2}$ in response to IL-1 stimulation $(p<0.001)$. Note that synoviocytes infected with Ad.RSVIL-Ira produced significantly less $\mathrm{PGE}_{2}$ over the $12 \mathrm{hr}$ of stimulation with IL-1 $\beta$ than cells infected with Ad.RSVlacZ $(p<0.001)$ or uninfected controls $(p<0.001)$. No significant difference was observed in the levels of $\mathrm{PGE}_{2}$ produced by mock-infected cells compared to Ad.RSVlacZ-infected cells $(p=0.067)$ after stimulation with IL-1.

centrifugation, and the concentration of human IL-1 ra present in pooled lavage fluid determined using ELISA. The results of these experiments are shown in Table 2. Evidence for transgenic expression of IL-1 ra was detected within the knees of rabbits infected with Ad.RSVIL-1ra at a dose of $2 \times 10^{10} \mathrm{pfu} /$ knee for at least 4 weeks post-infection. Peak intra-articular concentrations of IL-1 ra were noted 1 week post infection (13.9 $\mathrm{ng} / \mathrm{mg}$ total protein) followed by a decline to levels less than 1 $\log$ above the levels of IL-1ra present in joint lavage fluid obtained from controls 14 days post-infection. Although the levels of IL-1 ra present in infected knees were greater than the levels in control knees at 21 and 28 days post-infection, these differences did not reach statistical significance when analyzed by Student's $t$-test. Levels of IL-1ra present in the control knees infected with Ad.BglII or Ad.RSVlacZ remained below 50 $\mathrm{pg} / \mathrm{mg}$ of total protein throughout the observation period. The data obtained in this series of experiments correlate with those obtained using the in situ cRNA hybridization studies, indicating that temporal declines in the rate of transgene transcription occur in vivo with these first-generation adenoviral vectors.
These results are consistent with the observations of other investigators using first generation recombinant adenoviruses for transduction of other tissues (Rich et al., 1990; Rosenfeld et al., 1992; Engelhardt et al., 1993).

A second group of rabbits $(n=8)$ was injected with a single dose of Ad.RSVIL-l ra at a concentration of $1 \times 10^{11} \mathrm{pfu} / \mathrm{ml}$. At 4 and 7 days post-infection, all animals expressed high levels of intra-articular IL-1ra, while the levels of IL-1ra expression within the control knees (injected with $1 \mathrm{ml}$ of PBS) remained at baseline levels (Fig. 4). All of the animals expressed IL-lra at potentially therapeutic levels at both 4 days (mean intra-articular [IL-1 ra] $=8.98 \mathrm{ng} / \mathrm{mg}$ total protein) and 7 days (mean intraarticular [IL-1ra] $=3.88 \mathrm{ng} / \mathrm{mg}$ total protein) post-infection. Again, levels of transgenic protein expression had begun to decline by 7 days in all animals examined.

Although high levels of immunoreactive IL-1ra were detected in lavage fluid, an in vivo bioactivity assay was performed to test the anti-inflammatory capacity of the transgenic protein. Intra-articular administration of rhIL- $1 \alpha$ in rabbits has been shown to induce an acute inflammatory process that results in the degradation of cartilage matrix and the accumulation of GAG degradation products within the treated knees (Farndale et al., 1982). Exogenous recombinant human IL- $1 \alpha$ (rhIL$1 \alpha, 25 \mathrm{ng} / \mathrm{knee}$ ) was injected into the knees of three rabbits 4 days post-infection with Ad.RSVIL-lra and $24 \mathrm{hr}$ prior to sacrifice. As seen in Fig. 5, prior Ad.RSVIL-1ra injection resulted in a reduction in the amount of GAG degradation products by nearly half as compared with contralateral control knees (Ad.RSVIL-1ra-treated mean [GAG] $=42.9 \mu \mathrm{g} / \mathrm{ml}$; PBStreated mean $[\mathrm{GAG}]=88.1 \mu \mathrm{g} / \mathrm{ml} ; p \leqslant 0.03$ ). These data indicate that the secreted transgenic human IL-1 ra protein is not only immunoreactive, but retains bioactivity in vivo as measured by its ability to block articular inflammation mediated by exogenously administered recombinant human IL-1 $\alpha$.

\section{DISCUSSION}

Current treatments for rheumatoid arthritis are associated with significant untoward effects and are largely ineffective in preventing end-organ damage, the destruction of articular cartilage and bone (Harris, 1990). Increasing evidence points to the pathophysiologic role of synoviocytes in erosive RA (Harris, 1992; Gay et al., 1993; Zvaifler and Firestein, 1994). Rheumatoid synoviocytes, which persist in a semitransformed phenotype, are thought to mediate articular degradation by secreting matrix metalloproteases (e.g., collagenases, elastase, and stromelysin) and by elaborating proinflammatory cytokines (Brinkerhoff and Harris, 1978; Burmester et al., 1987; Case et al., 1989; Alvaro-Gracia et al., 1990; Chu et al., 1991; Koch et al., 1992; Rosenbaum et al., 1992).

Repeated intra-articular corticosteroid injections are the current mainstay in managing the most problematic joints in aggressive RA (Weiss, 1989; Firestein et al., 1991). Gene transfer strategies that mediate the intra-articular expression of antiinflammatory molecules would be expected to have similar therapeutic utility if applied in such cases. This approach would allow treatments to be directed specifically at the most severely affected joints, with the goal being the amelioration of joint destruction and the preservation of joint function. 


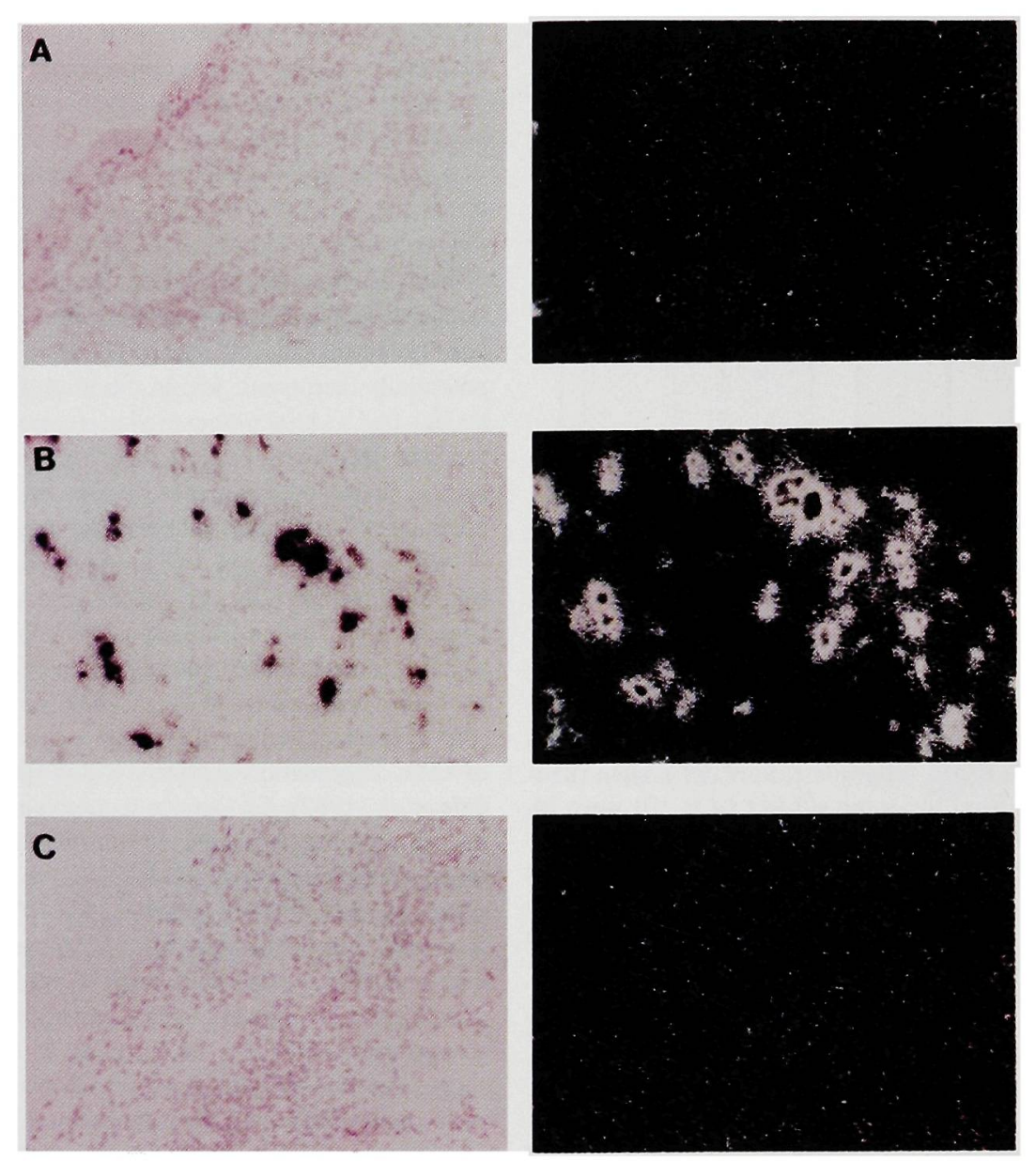

FIG. 3. In situ RNA hybridization of Ad.RSVIL-I ra-transduced synovial tissues. Sections of synovial tissue were obtained from NZW rabbits 1 week after infection with Ad.RSVIL-I $\mathrm{ra}$, and used for in situ RNA hybridization experiments to detect transgene transcription. ${ }^{35}$ S-Labeled sense and antisense RNA probes specific for human IL-1 ra were prepared by in vitro transcription using T7 polymerase and $\left[{ }^{35} \mathrm{~S}\right]$ UTP. Hybridizations were performed in $50 \%$ formamide at $58^{\circ} \mathrm{C}$ using previously described methods (Roessler et al., 1993). Slides were coated with photographic emulsion (Kodak NTB-2) and exposed for 4 days, developed, counterstained, and examined using a combination of light-field (left panels) and dark-field (right panels) microscopy to identify cells containing areas of specific antisense probe hybridization. Sections from Ad.RSVIL-I ra (B) or Ad.RSVlacZ (C) -infected animals were hybridized to radiolabeled antisense sequences, with only Ad.RSVIL-1 ra-infected tissues showing multiple positive cells. Synovial tissue from rabbits infected with Ad.RSVIL-I ra hybridized to sense probe exhibited background levels of signal (A).

Because IL-1 appears to be a pivotal cytokine in RA, the intra-articular overexpression of IL-1ra, its natural antagonist, would be expected to ameliorate the severity of IL-1-induced synovial inflammation. The previously reported expression of both IL- 1 and type I IL-1 receptors by human rheumatoid synoviocytes lends additional support to this hypothesis (Deleuran et al., 1992). In this report, we have shown that the direct intra-articular administration of a recombinant adenovirus can be used to mediate the transgenic expression of biologically active IL-1ra in both human and rabbit synoviocytes. The recombinant adenovirus was designed to prevent expression of viral genes that might in and of themselves have immunomodulatory effects. Therefore, we believe that our data do not indicate that any of these genes are responsible for the observed effects on $\mathrm{PGE}_{2}$ production in vitro or on GAG degradation products in vivo. We believe that the biological effects demon- strated both in vitro and in vivo are modulated specifically by the transgenic human IL-1a produced by transduced synoviocytes.

These results are similar to those recently reported using an ex viv' system of retroviral gene transfer to autologous synoviocytes followed by intra-articular transplantation for the regional expression of transgenic IL-1 ra (Bandara et al., 1993). The intra-articular levels of IL-1 ra recovered at 1 week were notably higher using direct in vivo gene transfer with recombinant adenoviruses compared to intra-articular transplantation of retrovirally transduced cells ( $\sim 5.0 \mathrm{ng}$ i's. $0.1 \mathrm{ng}$ of IL-1ra/knee). Besides this improved transgene expression, a number of other potential advantages of intra-articular adenoviral injection over an ex vivo transduction strategy are apparent. The current approach does not require the surgical acquisition, isolation, and culture of autologous synoviocytes. Further, the recombinant 
TABle 2. In Vivo EXPRESSION OF HUMAN IL-1Ra PROTEIN BY RABBIT SYNOVIUM 1 TO 4 WEEKS POST-INFECTION WITH AD.RSVIL-IRA.

\begin{tabular}{lccc}
\hline & \multicolumn{3}{c}{$[\text { [L-Ira }]^{\mathrm{a}}$} \\
\cline { 2 - 4 } Week & ${\text { Right } \text { knee }^{\mathrm{b}}}$ Left knee $^{\mathrm{c}}$ & $p$ \\
\hline 1 & $13.9 . \pm 1.8$ & $0.0494 \pm 0.0115$ & 0.004 \\
2 & $0.0936 \pm 0.0241$ & $0.0224 \pm 0.0112$ & 0.146 \\
3 & $\mathbf{0 . 0 7 6 8 \pm 0 . 0 3 4 7}$ & $0.0071 \pm 0.0071$ & $\mathbf{0 . 1 2 0}$ \\
4 & $0.0543 \pm 0.0311$ & $0.0048 \pm 0.0048$ & 0.199 \\
\hline
\end{tabular}

NZW rabbits $(n=4)$ received a single intra-articular dose of Ad. RSVIL-Ira $\left(2 \times 10^{10} \mathrm{pfu} / \mathrm{ml}\right.$; total volume $\left.1 \mathrm{ml}\right)$ into the right knee, and at the same time the left knee was injected with $1 \mathrm{ml}$ of PBS. The animals were then sacrificed at weekly intervals and analyzed for transgene expression present within infected synovium. At the time of sacrifice, the knees were lavaged with $2 \mathrm{ml}$ of PBS, cellular debris was removed by centrifugation, and the recovered fluid was frozen at $-70^{\circ} \mathrm{C}$ until use. The concentration of human IL-l ra in the lavage fluid was determined using an ELISA specific for IL-1ra, and the total protein concentration was determined using the method of Lowry. The values were recorded as $\mathrm{ng}$ of $1 \mathrm{~L}-\mathrm{lra} / \mathrm{mg}$ of total protein present in the lavage fluids.

${ }^{\text {a}}$ IL-1 $\mathrm{ra}$ (ng/mg total protein).

${ }^{\mathrm{b}}$ Ad.RSVIL-Ira.

'PBS control.

adenoviral strategy allows for the transduction of both type $A$ and type B synoviocytes (Roessler et al., 1993), as well as other cell types residing in the subsynovial connective tissue. This may prove to be therapeutically important. Although the synovium is often construed as a simple construct, it is actually a complex mesothelium with highly integrated structure and function, and transduction of multiple cell types may be required for a clinical effect.

The major limitation to the approach we have presented is that in vivo, peak levels of expression were detected at 4-7 days post-infection and then progressively declined. These results are identical to those observed in other organ systems transduced with recombinant adenoviruses. Although IL-1ra transgene expression was detectable for up to 1 month using adenoviral transduction, the use of an ex vivo system has been reported to result in detectable levels of IL-1 ra expression for up to 3 months (Bandara et al., 1993). New recombinant adenoviruses with temperature-sensitive mutations in early gene $2 \mathrm{~A}$ have been developed that result in prolonged expression (several months vs. 21 days) in liver and lung (Engelhardt et al., $1994 a, b)$. The production of second-generation adenoviruses for the prolonged in vivo expression of human IL-1ra are currently underway.

In summary, this report has shown that recombinant adenoviral vectors can mediate expression of human IL-1 ra by synovial tissues in vitro and in vivo, and demonstrates that adenovirally transduced synoviocytes can mediate expression of a secreted anti-inflammatory protein. Importantly, the transgenic protein retains biological activity in vitro and in vivo as measured by its ability to block the proinflammatory effects of exogenously administered human IL-1.

FIG. 4. Detection of transgenic human IL1 ra bioactivity in vivo. NZW rabbits $(n=8)$ were injected with a single intra-articular dose of Ad.RSVIL-Ira to determine if the levels of transgenic IL-1 ra produced in vivo varied significantly between animals. The right knee of the recipient animals received Ad.RSVIL-l ra $\left(1 \times 10^{11} \mathrm{pfu} / \mathrm{ml}\right.$, total volume $\left.1 \mathrm{ml}\right)$, while the left knee was injected with $1 \mathrm{ml}$ of vehicle alone (PBS containing 3\% glycerol and $0.1 \%$ BSA). The animals were sacrificed at 4 days and 7 days post-infection, the joint spaces Ad.RSVIL-Ira were lavaged with $2 \mathrm{ml}$ of PBS, cellular debris was removed by centrifugation, and the recovered fluid was frozen at $-70^{\circ} \mathrm{C}$ until use. The concentration of human IL-1 ra present in the lavage fluid was determined using an ELISA specific for IL-1 ra and expressed as nanograms of IL-1 ra/mg total protein present in the recovered lavage fluid (Fig. 4). Therapeutically relevant amounts of human IL-1 ra were present within the joint space of animals treated with Ad.RSVIL-Ira (ㅁ) at both 4 and 7 days postinfection, while the levels of endogenous IL1 ra present within the contralateral control knee $(\diamond)$ remained below $0.150 \mathrm{ng} / \mathrm{mg}$ total protein $(p<=0.008)$. Levels of transgenic human IL-1ra produced by the rabbits were highest at 4 days post-infection and had begun to decline by 7 days post-infection. Error bars indicate the standard deviation observed among 4 animals at each time point. 


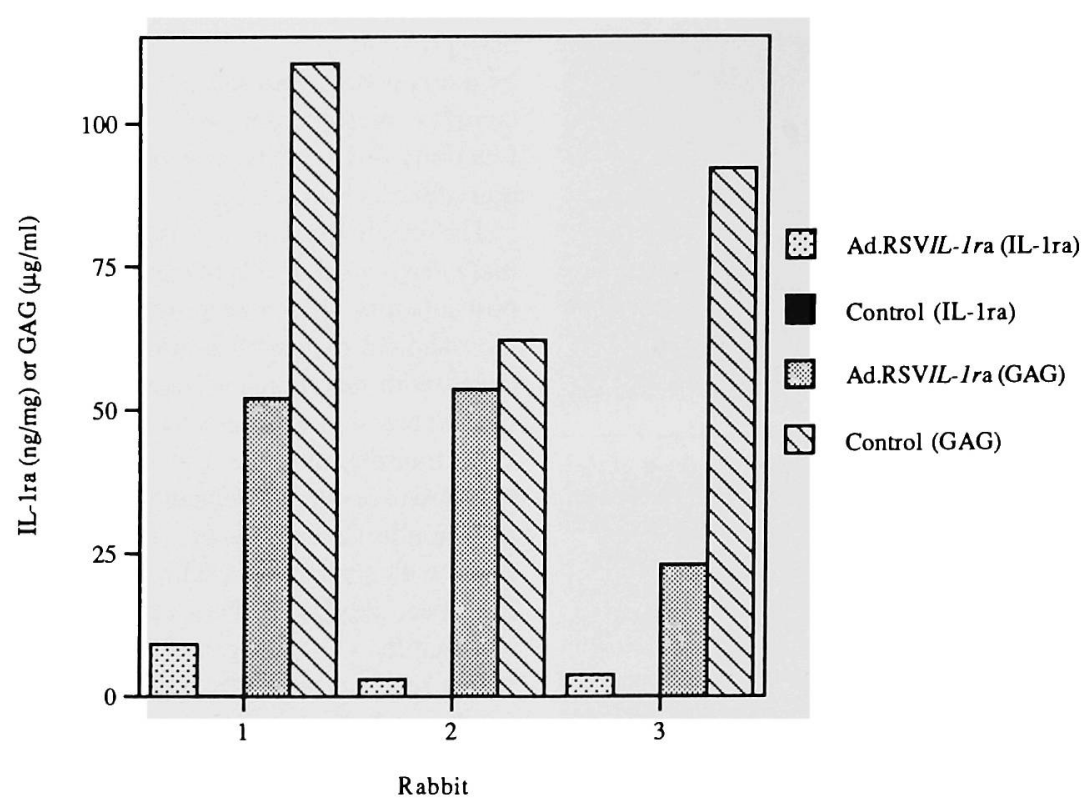

FIG. 5. Bioactive IL-1ra is expressed following Ad.RSVIL-1 ra transduction of synovial tissue. The hind knees of rabbits $(n=3)$ were injected with $25 \mathrm{ng}$ of human recombinant IL-1 $\alpha$ (Genzyme) in $0.5 \mathrm{ml}$ of PBS containing $3 \%$ glycerol and $0.1 \%$ BSA, either 3 days (rabbit 1 ) or 6 days (rabbits 2 and 3) after treatment with Ad.RSVIL-1 ra. Twenty-four hours after the injections of human recombinant IL- $1 \alpha$, the animals were sacrificed and the joint spaces were lavaged with 2 ml of PBS. The lavage fluids were then analyzed for human IL-1ra as well as total GAG concentration (Farndale et al., 1982). The results were expressed as nanograms of IL-1 ra/mg total protein, and micrograms of GAG/mL present within the recovered lavage fluid. The amount of IL-1-mediated GAG matrix (cartilage) degradation observed in the Ad.RSVIL-1 ra-treated knees was less than that observed in the contralateral control knees (Ad.RSVIL-Ira-treated mean [GAG] $=42.9 \mu \mathrm{g} / \mathrm{ml}$; PBS-treated mean [GAG] $=88.1 \mu \mathrm{g} / \mathrm{ml}$; $p<=0.03$ )

\section{ACKNOWLEDGMENTS}

The authors wish to thank Denis Schrier, Ph.D., and Susan Kuchera of Warner Lambert/Parke-Davis for performance of glycosaminoglycan assays and technical assistance; James $\mathbf{M}$. Wilson, M.D., Ph.D., Dick Simon, M.D., and Michael Imperiale, $\mathrm{Ph} . \mathrm{D}$., for critical discussions; and J.-M. Quevedo for expert secretarial assistance. This work was supported in part by the National Institutes of Health: R01 DK47968 and the University of Michigan Multipurpose Arthritis Center (P60 AR20557).

\section{REFERENCES}

ALVARO-GRACIA, J.M., ZVAIFLER, N.J., and FIRESTEIN, G.S. (1990). Cytokines in chronic inflammatory arthritis. V. Mutual antagonism between interferon-gamma and tumor necrosis factor-alpha on HLA-DR expression, proliferation, collagenase production, and granulocyte macrophage colony-stimulating factor production by rheumatoid arthritis synoviocytes. J. Clin. Invest. 86, 1790-1798.

AREND, W.P., JOSLIN, F.G., THOMPSON, R.C., and HANNUM, C.H. (1989). An IL-1 inhibitor from human monocytes. Production and characterization of biological properties. J. Immunol. 143, $1851-1858$.

AREND, W.P., WELGUS, H.G., THOMPSON, R.C., and EISENBERG, S.P. (1990). Biological properties of recombinant human monocyte-derived interleukin-1 receptor antagonist. J. Clin. Invest. 85, 1694-1697.
BANDARA, G., MUELLER, G.M., GALEA-LAURI, J., TINDAL, M.H., GEORGESCU, H.I., SUCHANEK, M.K., HUNG, G.L., GLORIOSO, J.C., ROBBINS, P.D., and EVANS, C.H. (1993), Intra-articular expression of biologically active interleukin-1-receptor-antagonist protein by ex vivo gene transfer. Proc. Natl. Acad. Sci. USA 90, 10764-10768.

BARLAND, P., NOVIKOFF, A.B., and HAMERMAN, D. (1962). Electron microscopy of the human synovial membrane. J. Cell. Biol. 14, 207-220.

BRINKERHOFF, C.E., and HARRIS, E.D., JR. (1978). Collagen production by cultures containing multinucleated cells derived from synovial fibroblasts. Arthritis Rheum. 21, 745-753.

BROKER, B.M., EDWARDS, J.C., FANGER, M.W., and LYDYARD, P.M. (1990). The prevalence and distribution of macrophages bearing Fc $\gamma$ RI, Fc $\gamma$ RII, and Fc $\gamma$ RIII in synovium. Scand. J. Rheumatol. 19, 123-135.

BURMESTER, G.R., JAHN, B., ROHWER, P., ZACHER, J., WINCHESTER, R.J., and KALDEN, J.R. (1987). Differential expression of Ia antigens by rheumatoid synovial lining cells. J. Clin. Invest. 80, 595-604.

CARTER, D.B., DEIBEL, M.R., DUNN, C.J., TOMICH, C.S., LABORDE, A.L., SLIGHTOM, J.L., BERGER, A.E., BIENKOWSKI, M.J., SUN, F.F., MCEWAN, R.N., HARRIS, P.K.W., YEM, A.M., WASZAK, G.A., CHOSAY, J.G., SIEU, L.C., HARDEE, M.M., ZURCHER-NEELY, H.A., REARDON, I.M., HEINRIKSON, R.L., TRUESDELL, S.E., SHELLY, J.A., EESSALU, T.E., TAYLOR, B.M., and TRACEY, D.E. (1990). Purification, cloning, expression and biological characterization of an interleukin- 1 receptor antagonist protein. Nature 344, 633-638.

CASE, J.P., LAFYATIS, R., REMMERS, E.F., KUMKUMIAN, G.K., and WILDER, R.L. (1989). Transin/stromelysin expression 
in rheumatoid synovium. A transformation-associated metalloproteinase secreted by phenotypically invasive synoviocytes. Am. J. Pathol. 135, 1055-1064.

CASTOR, C.W. (1971). Connective tissue activation. II. Abnormalities of cultured theumatoid synovial cells. Arthritis Rheum. 14, 55-66.

CHU, C.Q., FIELD, M., FELDMANN, M., and MAINI, R.N. (1991). Localization of tumor necrosis factor alpha in synovial tissues and at the cartilage-pannus junction in patients with rheumatoid arthritis. Arthritis Rheum. 34, 1125-1132.

DAVIDSON, B.L., ALLEN, E.D., KOZARSKY, K.F., WILSON, J.M. , and ROESSLER, B.J. (1993). A model system for in vivo gene transfer into the central nervous system using an adenoviral vector. Nature Genetics 3, 219-223.

DAYER, J.M., ZAVADIL-GROB, C., UCLA, C., and MACH, B. (1984). Induction of human interleukin 1 mRNA measured by collagenase- and prostaglandin E2-stimulating activity in rheumatoid synovial cells. Eur. J. Immunol. 14, 898-901.

DAYER, J.M., DE ROCHEMONTEIX, B., BURRUS, B., DEMCZUK, S., and DINARELLO, C.A. (1986). Human recombinant interleukin 1 stimulates collagenase and prostaglandin E2 production by human synovial cells. J. Clin. Invest. 77, 645-648.

DELEURAN, B.W., CHU, C.Q., FIELD, M., BRENNAN, F.M., KATSIKIS, P., FELDMANN, M., and MAINI, R.N. (1992). Localization of interleukin-I alpha, type $I$ interleukin- 1 receptor and interleukin-1 receptor antagonist in the synovial membrane and cartilage/pannus junction in rheumatoid arthritis. Br. J. Rheumatol. 31, 801-809.

DINARELLO, C.A. (1992). Reduction of inflammation by decreasing production of interleukin-1 or by specific receptor antagonism. Int. J. Tissue React. 14, 65-75.

EISENBERG, S.P., EVANS, R.J., AREND, W.P., VERDERBER, E., BREWER, M.T., HANNUM, C.H., and THOMPSON, R.C. (1990). Primary structure and functional expression from complementary DNA of a human interleukin- 1 receptor antagonist. Nature 343, 341-346.

ENGELHARDT, J.F., SIMON, R.H., YANG, Y., ZEPEDA, M., WEBER-PENDLETON, S., DORANZ, B., GROSSMAN, M., and WILSON, J.M. (1993). Adenovirus-mediated transfer of the CFTR gene to lung of non-human primates: Biological efficacy study. Hum. Gene Ther. 4, 759-769.

ENGELHARDT J.F., YE, X., DORANZ, B., and WILSON, J.M. (1994a). Ablation of E2a in recombinant adenoviruses improves transgene persistence and decreases inflammatory response in mouse liver. Proc. Natl. Acad. Sci. USA 91, 6190-6200.

ENGELHARDT, J.F., LITZKY, L., and WILSON, J.M. (1994b). Prolonged transgene expression in cotton rat lung with recombinant adenoviruses defective in E2a. Hum. Gene Ther. 5, 1217-1229.

FALKOFF, R.J., BUTLER, J.L., DINARELLO, C.A., and FAUCI, A.S. (1984). Direct effects of a monoclonal $B$ cell differentiation factor and of purified interleukin 1 on B cell differentiation. J. Immunol. 133, 692-696.

FARNDALE, R.W., SAYERS, C.A., and BARRETT, A.J. (I982). A direct spectrophotometric microassay for sulfated glycosaminoglycans in cartilage cultures. Connect. Tissue Res. 9, 247-248.

FIRESTEIN, G.S., PAINE, M.M., and LITTMAN, B.H. (1991). Gene expression (collagenase, tissue inhibitor of metalloproteinases, complement, and HLA-DR) in rheumatoid arthritis and osteoarthritis synovium. Quantitative analysis and effect of intraarticular corticosteroids. Arthritis Rheum. 34, 1094-1 105.

GAY, S., GAY, R.E., and KOOPMAN, W.J. (1993). Molecular and cellular mechanisms of joint destruction in rheumatoid arthritis: Two cellular mechanisms explain joint destruction (abstract). Ann. Rheum. Dis. 52, S39.

GRAHAM, F.L., and VAN DER EB, A.J. (1973). A new technique for the assay of infectivity of human adenovirus 5 DNA. Virology 52, 456-467.
HARRIS, E.D., JR. (1990). Rheumatoid arthritis. Pathophysiology and implications for therapy [published erratum appears in N. Engl. J. Med. 323, 996, 1990]. N. Engl. J. Med. 322, 1277-1289.

HARRIS, E.D., JR. (1992). Excitement in synovium: The rapid evolution of understanding of rheumatoid arthritis and expectations for therapy. J. Rheumatol. Suppl. 32, 3-5.

KOCH, A.E., KUNKEL, S.L., CHENSUE, S.W., HAINES, G.K., and STRIETER, R.M. (1992). Expression of interleukin-I and interleukin- 1 receptor antagonist by human rheumatoid synovial tissue macrophages. Clin. Immunol. Immunopathol. 65, 23-29.

KUMKUMIAN, G.K., LAFYATIS, R., REMMERS, E.F., CASE, J.P., KIM, S.J., and WILDER, R.L. (1989). Platelet-derived growth factor and $1 \mathrm{~L}-1$ interactions in rheumatoid arthritis. Regulation of synoviocyte proliferation, prostaglandin production, and collagenase transcription. J. Immunol. 143, 833-837.

LAFYATIS, R., REMMERS, E.F., ROBERTS, A.B., YOCUM, D.E., SPORN, M.B., and WILDER, R.L. (1989). Anchorage independent growth of synoviocytes from arthritic and normal joints: stimulation by exogenous platelet-derived growth factor and inhibition by transforming growth factor $\boldsymbol{\beta}$ and retinoids. J. Clin. Invest. 83, I267-1276.

LOGAN, J., and SHENK, T. (1984). Adenovirus tripartite leader sequence enhances translation of mRNA's late after infection. Proc. Natl. Acad. Sci. USA 81, 3655-3659.

MECROSKERY, P.A., ARAl, S., AMENTO, E.P., and KRANE, S.M. (1985). Stimulation of procollagenase synthesis in human rheumatoid synovial fibroblasts by mononuclear cell factor/interleukin 1 . FEBS Lett. 191, 7-12.

MOSSEC,P., DINARELLO, C.A., and ZIFF, M. (1986). Interleukin-I lymphocyte chemotactic activity in rheumatoid arthritis synovial fluid. Arthritis Rheum. 29, 461-470.

MIZEL, S.B., DAYER, J.M., KRANE, S.M., and MERGENHAGEN, S.E. (I981). Stimulation of rheumatoid synovial cell collagenase and prostaglandin production by partially purified lymphocyte-activating factor (interleukin 1). Proc. Natl. Acad. Sci. USA 78, 2474-2477.

MOCHAN, E., ULH, J., and NEWTON, R. (1986). Interleukin I stimulation of synovial cell plasminogen activator production. J. Rheumatol. 13, 15-19.

RICH, D.P., ANDERSON, M.P., GREGORY, R.J., CHENG, S.H., PAUL, S., JEFFERSON, D.M., MCCANN, J.D., KLINGER, K.W., SMITH, A.E., and WELSH, M.J. (1990). Expression of cystic fibrosis transmembrane conductance regulator corrects defective chloride channel regulation in cystic fibrosis airway epithelial cells. Nature 347, 358-363.

ROESSLER, B.J., ALLEN, E.D., WILSON, J.M., HARTMAN, J.W., and DAVIDSON, B.L. (1993). Adenoviral mediated gene transfer of rabbit synovium in vivo. J. Clin. Invest. 92, 1085-1092.

ROSENBAUM, J.T., CUGNINI, R., TARA, D.C., HEFENEIDER, S., and ANSEL, J.C. (1992). Production and modulation of interleukin 6 synthesis by synoviocytes derived from patients with arthritic disease. Ann. Rheum. Dis. 51, 198-202.

ROSENFELD, M.A., YOSHIMURA, K., TRAPNELL, B.C., YONEYAMA, K., ROSENTHAL, E.R., DALEMANS, W., FUKAYAMA, M., BARGON, J., STIER, L.E., STRATFORDPERRICAUDET, L., PERRICAUDET, M., GUGGINO, W.B., PAVIRANI, A., LECOCQ, J.-P., and CRYSTAL, R.C. (1992). In vivo transfer of the human cystic fibrosis transmembrane conductance regulator gene to the airway epithelium. Cell 68, 143-155.

ROY, S., GHADIALLY, F.N., and CRANE, W.A. (1966). Synovial membrane in traumatic effusion. Ultrastructure and autoradiography with tritiated leucine. Ann. Rheum. Dis. 25, 259-271.

SECKINGER, P., WILLIAMSON, K., BALAVOINE, J.F., MACH, B., MAZZEI, G., SHAW, A., and DAT'ER, J.M. (1987). A urine inhibitor of interleukin-1 activity affects both interleukin- $1 \alpha$ and $1 \beta$ but not tumor necrosis factor. J. Immunol. 139, 1541-1545. 
SECKINGER, P., YARON, I., MEYER, F.A., YARON, M., and DAYER, J.M. (1990). Modulation of the effects of interleukin-1 on glycosaminoglycan synthesis by the urine-derived interleukin-1 inhibitor, but not by interleukin-6. Arthritis Rheum. 33, 1807-1814.

SMITH, K.A., LACHMAN, L.B., OPPENHEIM, J.J., and FAVATA, M.F. (1980). The functional relationship of the interleukins. J. Exp. Med. 151, 1551-1561.

STASHENKO, P., DEWHIRST, F.E., PEROS, W.J., KENT, R.L., and AGO, J.M. (1987). Synergistic interactions between interleukin 1 , tumor necrosis factor, and lymphotoxin in bone resorption. J. Immunol. 138, 1464-1468.

WEISS, M.M. (1989). Corticosteroids in rheumatoid arthritis. Semin. Arthritis Rheum. 19, 9-21.

WOOD, D.D., IHRIE, E.J., and HAMERMAN, D. (1985). Release of interleukin- I from human synovial tissue in vitro. Arthritis Rheum. 28, 853-862.

YARON, I., MEYER, F.A., DAYER, J.M., and YARON, M. (1987). Human recombinant interleukin-1 beta stimulates glycosaminogly- can production in human synovial fibroblast cultures. Arthritis Rheum. 30, 424-430.

ZVAIFLER, N.J., and FIRESTEIN, G.S. (1994). Pannus and pannocytes. Alternative models of joint destruction in rheumatoid arthritis. Arthritis Rheum. 37, 783-789.

\author{
Address reprint requests to: \\ Dr. Blake J. Roessler \\ University of Michigan Medical Center \\ 5520 MSRB I, Box 0680 \\ 1150 West Medical Center Drive \\ Ann Arbor, MI 48109-0680
}

Received for publication June 23, 1994; accepted after revision November 15, 1994. 


\section{This article has been cited by:}

1. Sophie Morisset, David D Frisbie, Paul D Robbins, Alan J Nixon, C Wayne Mcllwraith. 2007. IL-1ra/IGF-1 Gene Therapy Modulates Repair of Microfractured Chondral Defects. Clinical Orthopaedics and Related Research 462, 221-228. [CrossRef]

2. Paul E. Di Cesare, Sally R. Frenkel, Cathy S. Carlson, Carrie Fang, Chuanju Liu. 2006. Regional gene therapy for full-thickness articular cartilage lesions using naked DNA with a collagen matrix. Journal of Orthopaedic Research 24:5, 1118-1127. [CrossRef]

3. Keri Csencsits, Sherri Chan Wood, Guanyi Lu, D. Keith Bishop. 2005. Transforming Growth Factor-Beta1 Gene Transfer is Associated with the Development of Regulatory Cells. American Journal of Transplantation 5:10, 2378-2384. [CrossRef]

4. Jae-Gyun Jeong, Jong-Mook Kim, Seong-Hyun Ho, Woong Hahn, Seung Shin Yu, Sunyoung Kim. 2004. Electrotransfer of human IL-1Ra into skeletal muscles reduces the incidence of murine collagen-induced arthritis. The Journal of Gene Medicine 6:10, 1125-1133. [CrossRef]

5. Martin Braddock, Anthony Quinn, Jan Canvin. 2004. Therapeutic potential of targeting IL-1 and IL-18 in inflammation. Expert Opinion on Biological Therapy 4:6, 847-860. [CrossRef]

6. Andrei V. Maksimenko, Vasilii Mandrouguine, Marina B. Gottikh, Jean-Remi Bertrand, Jean-Pierre Majoral, Claude Malvy. 2003. Optimisation of dendrimer-mediated gene transfer by anionic oligomers. The Journal of Gene Medicine 5:1, 61-71. [CrossRef]

7. Natacha Bessis, Christelle Doucet, Virginie Cottard, Anne-Marie Douar, HDseyin Firat, Christian Jorgensen, Mauro Mezzina, Marie-Christophe Boissier. 2002. Gene therapy for rheumatoid arthritis. The Journal of Gene Medicine 4:6, 581-591. [CrossRef]

8. Rachel A. Saxer, Stephen J. Bent, Brent D. Brower-Toland, Zhibao Mi, Paul D. Robbins, Christopher H. Evans, Alan J. Nixon. 2001. Gene mediated insulin-like growth factor-I delivery to the synovium. Journal of Orthopaedic Research 19:5, 759-767. [CrossRef]

9. Brent D. Brower-Toland, Rachel A. Saxer, Laurie R. Goodrich, Zhibao Mi , Paul D. Robbins , Christopher H. Evans, Alan J. Nixon . 2001. Direct Adenovirus-Mediated Insulin-Like Growth Factor I Gene Transfer Enhances Transplant Chondrocyte FunctionDirect Adenovirus-Mediated Insulin-Like Growth Factor I Gene Transfer Enhances Transplant Chondrocyte Function. Human Gene Therapy 12:2, 117-129. [Abstract] [PDF] [PDF Plus]

10. Qingping Yao, Joseph C. Glorioso, Christopher H. Evans, Paul D. Robbins, Imre Kovesdi, Thomas J. Oligino, Steven C. Ghivizzani. 2000. Adenoviral mediated delivery of FAS ligand to arthritic joints causes extensive apoptosis in the synovial lining. The Journal of Gene Medicine 2:3, 210-219. [CrossRef]

11. E. Lubberts, L. A. B. Joosten, L. Van Den Bersselaar, M. M. A. Helsen, A. C. Bakker, Z. Xing, C. D. Richards, W. B. Van Den Berg. 2000. Intra-articular IL-10 gene transfer regulates the expression of collagen-induced arthritis (CIA) in the knee and ipsilateral paw. Clinical and Experimental Immunology 120:2, 375-383. [CrossRef]

12. Cem Gabay. 2000. IL-1 inhibitors: novel agents in the treatment of rheumatoid arthritis. Expert Opinion on Investigational Drugs 9:1, 113-127. [CrossRef]

13. Takashi Yokoo, Toya Ohashi , Yasunori Utsunomiya, Hiromi Kojima, Toshiyuki Imasawa, Taroh Kogure , Yutaka Hisada, Masaru Okabe, Yoshikatsu Eto , Tetsuya Kawamura, Tatsuo Hosoya . 1999. Prophylaxis of Antibody-Induced Acute Glomerulonephritis with Genetically Modified Bone Marrow-Derived Vehicle CellsProphylaxis of Antibody-Induced Acute Glomerulonephritis with Genetically Modified Bone Marrow-Derived Vehicle Cells. Human Gene Therapy 10:16, 2673-2678. [Abstract] [PDF] [PDF Plus]

14. Theodore J. Standiford, Jodi M. Wilkowski, Thomas H. Sisson, Noboru Hattori, Borna Mehrad, Kathy A. Bucknell, Thomas A. Moore . 1999. Intrapulmonary Tumor Necrosis Factor Gene Therapy Increases Bacterial Clearance and Survival in Murine Gram-Negative PneumoniaIntrapulmonary Tumor Necrosis Factor Gene Therapy Increases Bacterial Clearance and Survival in Murine Gram-Negative Pneumonia. Human Gene Therapy 10:6, 899-909. [Abstract] [PDF] [PDF Plus]

15. C. H. Evans, S. C. Ghivizzani, R. Kang, T. Muzzonigro, M. C. Wasko, J. H. Herndon, P. D. Robbins. 1999. Gene therapy for rheumatic diseases. Arthritis \& Rheumatism 42:1, 1-16. [CrossRef] 
16. Kazuhisa Otake, David L. Ennist, Kevin Harrod, Bruce C. Trapnell. 1998. Nonspecific Inflammation Inhibits Adenovirus-Mediated Pulmonary Gene Transfer and Expression Independent of Specific Acquired Immune ResponsesNonspecific Inflammation Inhibits Adenovirus-Mediated Pulmonary Gene Transfer and Expression Independent of Specific Acquired Immune Responses. Human Gene Therapy 9:15, 2207-2222. [Abstract] [PDF] [PDF Plus]

17. Guo-Yuan Yang, Xiao-Hong Liu, Chitoshi Kadoya, Yong-Jie Zhao, Ying Mao, Beverly L. Davidson, A. Lorris Betz. 1998. Attenuation of Ischemic Inflammatory Response in Mouse Brain Using an Adenoviral Vector to Induce Overexpression of Interleukin-1 Receptor Antagonist. Journal of Cerebral Blood Flow \& Metabolism 840-847. [CrossRef]

18. William P. Arend, Mark Malyak, Carla J. Guthridge, Cem Gabay. 1998. INTERLEUKIN-1 RECEPTOR ANTAGONIST: Role in Biology. Annual Review of Immunology 16:1, 27-55. [CrossRef]

19. Fuad Mehraban, Sriram Kasturi. 1998. Gene transfer of type 1 interleukin-1 receptor extracellular-domain complementary DNA into rabbit synovial cell line HIG-82 results in cellular blockade of interleukin-1 signal transduction. Arthritis \& Rheumatism 41:3, 515-524. [CrossRef]

20. CH Evans, PD Robbins. 1997. Gene therapy for arthritis. Expert Opinion on Investigational Drugs 6:7, 837-840. [CrossRef]

21. Theodore H. Welling, Beverly L. Davidson, Jennifer A. Zelenock, James C. Stanley, David Gordon, Blake J. Roessler, Louis M. Messina. 1996. Systemic Delivery of the Interleukin-1 Receptor Antagonist Protein Using a New Strategy of Direct Adenoviral-Mediated Gene Transfer to Skeletal Muscle Capillary Endothelium in the Isolated Rat HindlimbSystemic Delivery of the Interleukin-1 Receptor Antagonist Protein Using a New Strategy of Direct Adenoviral-Mediated Gene Transfer to Skeletal Muscle Capillary Endothelium in the Isolated Rat Hindlimb. Human Gene Therapy 7:15, 1795-1802. [Abstract] [PDF] [PDF Plus]

22. SHOU-NAN YAO, AYAD FARJO, BLAKE J. ROESSLER, BEVERLY L. DAVIDSON, KOTOKU KURACHI. 1996. Adenovirus-Mediated Transfer of Human Factor IX Gene in Immunodeficient and Normal Mice: Evidence for Prolonged Stability and Activity of the Transgene in LiverAdenovirus-Mediated Transfer of Human Factor IX Gene in Immunodeficient and Normal Mice: Evidence for Prolonged Stability and Activity of the Transgene in Liver. Viral Immunology 9:3, 141-153. [Abstract] [PDF] [PDF Plus] 